\title{
Profound morphological and functional changes of rodent Purkinje cells between the first and the second postnatal weeks: a metamorphosis?
}

\author{
Isabelle Dusart ${ }^{1,2 *}$ and Frederic Flamant ${ }^{3}$ \\ ' Equipe Différenciation Neuronale et Gliale, Université Pierre et Marie Curie, Paris, France \\ ${ }^{2}$ Centre National de la Recherche Scientifique, Neurobiologie des Processus Adaptatifs, Paris, France \\ ${ }^{3}$ École Normale Supérieure de Lyon, Centre National de la Recherche Scientifique, Institut de Génomique Fonctionnelle de Lyon, Lyon, France
}

\section{Edited by:}

Salvador Martinez, University

Miguel Hernandez, Spain

\section{Reviewed by:}

Ferdinando Rossi, University of Turin, Italy

Constantino Sotelo, University

Pierre and Marie Curie, France

\section{*Correspondence:}

Isabelle Dusart, Equipe

Différenciation Neuronale et Gliale,

Université Pierre et Marie Curie,

UMR7102, NPA, Bat B, 6eme,

Case 12, 9 Quai Saint Bernard,

75005 Paris, France.

e-mail: isabelle.dusart@upmc.fr
Between the first and the second postnatal week, the development of rodent Purkinje cells is characterized by several profound transitions. Purkinje cells acquire their typical dendritic "espalier" tree morphology and form distal spines. During the first postnatal week, they are multi-innervated by climbing fibers and numerous collateral branches sprout from their axons, whereas from the second postnatal week, the regression of climbing fiber multi-innervation begins, and Purkinje cells become innervated by parallel fibers and inhibitory molecular layer interneurons. Furthermore, their periods of developmental cell death and ability to regenerate their axon stop and their axons become myelinated. Thus a Purkinje cell during the first postnatal week looks and functions differently from a Purkinje cell during the second postnatal week. These fundamental changes occur in parallel with a peak of circulating thyroid hormone in the mouse. All these features suggest to some extent an interesting analogy with amphibian metamorphosis.

Keywords: Purkinje cell, development

\section{INTRODUCTION}

Understanding how brain complexity develops is one of the challenges of neurobiology. Neurons and glia mature in a succession of transitions between cell states. The orchestration of these processes for different cell types requires the tight regulation of both intrinsic and extrinsic factors. Although each cell type undergoes its own program of differentiation, the timing of differentiation must be coordinated between different cell types. Thus, during brain formation, the regulation of cell number and the precise timing of differentiation require the interplay between intrinsic programs of development and extrinsic factors.

The rodent cerebellum is an attractive model system for the study of cell differentiation, as it consists of a small number of neuronal types that have been morphologically and molecularly well characterized (for review see Armengol and Sotelo, 1991; Sotelo, 2004). Three major types of neurons with very different properties are found in the cerebellar cortex: Purkinje cells, granule cells, and GABAergic interneurons (basket, stellate, and Golgi neurons). They differ in their function, morphology, origin, migration routes, and differentiation timing. Neurogenesis in the cerebellum extends over a protracted period of time, between embryonic day 10.5 and postnatal day 15 in mice, and parallels glial cell proliferation and differentiation. As a consequence, successive steps in the differentiation of several cerebellar cell types are spread over a long time period.

Purkinje cells, some of the largest neurons in the central nervous system, have a central place among the different cell populations of the cerebellar cortex. Purkinje cells are the only efferents of the cerebellar cortex, mainly sending inhibitory projections to the deep cerebellar nuclei, and thus constitute the sole output for all motor coordination and learning from the cerebellar cortex. Many fundamental concepts of modern neuroscience have been established by a focus on this spectacular cell type (see review Sotelo, 2004). They are the targets of numerous naturally occurring neurological mutations (Dusart et al., 2006; Sajan et al., 2010). 5-hydroxy-methyl-cytosine, a modified nucleotide which function remains enigmatic, was first discovered in Purkinje cell DNA (Kriaucionis and Heintz, 2009). Furthermore, Purkinje cells, being the only output of the cerebellar cortex, control the function of the cerebellum. Thus, when Purkinje cells are affected, it is very easy to detect through behavioral phenotypes. Furthermore, their typical location and morphology make them very easy to study. For these reasons, they have been more frequently studied than other neurons and consequently they have been more often detected as implicated in pathologies. The Purkinje cell constitutes thus a classical model to study a number of aspects of neuronal differentiation.

Purkinje cells are the first neuron of the cerebellar cortex to be generated; they are born during the early fetal development (embryonic days 11-13 in mice, Miale and Sidman, 1961; Carletti and Rossi, 2008); they end their phase of migration 2 or 3 days before birth and their axons reach their targets in the deep cerebellar nuclei by the end of the fetal period (embryonic day 17, Eisenman et al., 1991). Between embryonic day 19 and the day of birth, Purkinje cells receive their first climbing fiber synapses (Mason et al., 1990; Chedotal and Sotelo, 1992). However, the development of mouse Purkinje cells occurs largely during the first three postnatal weeks of life, during which Purkinje cells 
develop dendrites and establish synaptic connections (Sotelo and Dusart, 2009). Although it largely coincides with granule cell proliferation and maturation of GABAergic interneuron precursors in neighboring cerebellar layers, the postnatal Purkinje cell maturation process is probably also governed by an intrinsic genetic program.

The aim of this review is to focus on the events that occur during the transition between the first and the second postnatal week and to investigate to which extent these events can be driven by the peak of circulating thyroid hormone that occurs at the end of the first postnatal week in the mouse.

\section{THE END OF THE FIRST POSTNATAL WEEK: A PERIOD OF TRANSITION IN PURKINJE CELL DIFFERENTIATION DENDRITIC DIFFERENTIATION \\ Morphological transition at the end of the first postnatal week}

Shortly after birth, cerebellar Purkinje cells have a bipolar shape reminiscent of their migratory morphology, with a primary dendrite at their apical pole and an axon at the basal pole. Ramon y Cajal was the first to describe this stage, which he called "phase of fusiform corpuscle" (Cajal, 1926). In 1991, Armengol and Sotelo described two types of fusiform stages in the rat: a simple fusiform corresponding to Cajal's description, and a complex fusiform, presenting a more elaborated dendritic tree in which some collateral branches develop from the primary dendrites (Armengol and Sotelo, 1991). Around postnatal day 3 in rats, the primary dendrite has regressed, in parallel with the emergence of numerous perisomatic dendritic processes. At this stage, the Purkinje cells are not polarized, and Cajal called this stage "stellate." Several different stellate stages have since been more precisely described (Armengol and Sotelo, 1991). At least two different morphological types can be distinguished: a true stellate form, in which the processes are thin, long, and without spines, and an atrophic stage, in which the processes are short. A third intermediate type has also been described in which few (two or three) dendrites emerge from the soma at the apical pole. Interestingly, the small dendrites of this later stage have spines. All these stages can be visualized in parallel during the first postnatal week, as the development of the cerebellar cortex is not synchronous: different developmental stages can coexist within a same lobule and among neighboring Purkinje cells (Armengol and Sotelo, 1991). Only video-microscopy would show whether all the Purkinje cells go through these different stages and in which order. However, the study of the proportions of cells in the different stages over time either in vivo in rats (Armengol and Sotelo, 1991) or ex vivo in organotypic cultures (Boukhtouche et al., 2006b; Poulain et al., 2008) suggests that the Purkinje cells pass through these different stages in the described order (Sotelo and Dusart, 2009).

At the beginning of the second postnatal week, the Purkinje cells have a single stem segment at their apical pole. From this time, a "cerebellist" can easily recognize the early form of the future mature Purkinje cell dendritic tree. One particularity of this dendritic tree is that the growth and the ramification occur in the sagittal plane (Kaneko et al., 2011). Thus, as described by Cajal, mature Purkinje cell dendritic tree resembles an "espaliered" fruit tree (Cajal, 1911). Larramendi proposed that this transition from multiple dendritic trees to a single one could be the result of the sudden drop of the Purkinje cell nucleus toward the basal pole (Larramendi, 1969). In parallel with this transition, Purkinje cell somata merge from multiple irregular rows into a single layer. During the second postnatal week, and up to the end of the third postnatal week, the dendritic tree grows first wider and then taller (Berry and Bradley, 1976).

\section{Morphological changes: cell-autonomous versus non-cell-autonomous processes}

The first dendritic differentiation phases are likely to be driven by intrinsic Purkinje cell developmental programs. The very few purified newborn mouse Purkinje cells $(0.2 \%)$ that survive in dissociated culture have smaller dendrites after 21 days in vitro than after 4 days in vitro, suggesting that the regressive events occur in vitro (Baptista et al., 1994). In these culture conditions, Purkinje cells never acquire their typical dendritic form. In organotypic culture, Purkinje cells grown in the absence of climbing fiber present similar dendritic developmental phases as those described in vivo (Boukhtouche et al., 2006b; Poulain et al., 2008), suggesting that climbing fibers are not necessary for the general sculpting of the dendritic trees. However, in the absence of climbing fibers, the size of the dendritic tree was reduced, due to a decrease in the total number of dendritic segments whereas individual segment lengths were largely unaltered (Bradley and Berry, 1976). In contrast, the study of experimental models or mutant mice in which the development of parallel fibers is impeded has revealed that parallel fibers are very important for the growth and planar arrangement of the mature dendritic tree (for review see Sotelo and Dusart, 2009). Thus, although the first postnatal phases of Purkinje cell dendritic differentiation are likely to be intrinsic, the later phases occurring from the second postnatal week dependent on the environment.

An interesting example of the importance of intrinsic factors has been described for the nuclear receptor $\operatorname{ROR} \alpha$, which is deleted in staggerer mouse (Hamilton et al., 1996). The effect of this mutation on Purkinje cells has been long known (Sidman et al., 1962; Boukhtouche et al., 2006a; Gold et al., 2007). More recently, the role of ROR $\alpha$ in the first stages of Purkinje cell dendritic development has been studied using lentiviral ROR $\alpha$ overexpression in organotypic culture of newborn cerebellar slices (Boukhtouche et al., 2006b). In this model, 58\% of ROR $\alpha$ transduced Purkinje cells are already in an atrophic stage after 3 days of culture, while $94 \%$ of control Purkinje cells are still in the fusiform stages. After 5 days in culture, $57 \%$ of the transduced Purkinje cells are already in a mature stage and present numerous spines. These results indicate that the overexpression of $\mathrm{ROR} \alpha$ first promotes the regression of the primary dendritic tree and then accelerates dendritic development (Boukhtouche et al., 2006b). Later over-expression does not alter Purkinje cell morphology, suggesting a restriction of the developmental function of ROR $\alpha$ to early stages (Boukhtouche et al., 2006b). Although the growth of the characteristic form of Purkinje cells is dependent of the environment (for review see Sotelo and Dusart, 2009), the factors that drive its specific form are still unknown. 


\section{TRANSITION OF SYNAPTIC COMPONENTS AT THE END OF THE FIRST POSTNATAL WEEK \\ General description of the development of synaptic connections on Purkinje cells}

Purkinje cells are at the center of the cerebellar neuronal circuit. Each Purkinje cell receives up to 200000 synapses and transmits the integrated signal to the deep nuclei. The innervation of Purkinje cells undergoes profound modifications during the first two postnatal weeks. As it has been recently reviewed, cerebellar developing circuits typically differ substantially from their mature counterparts, which suggests that development may not simply involve synaptic refinement, but rather involves restructuring of key synaptic components and network connections, in a manner reminiscent of metamorphosis (van Welie et al., 2011).

Purkinje cells establish functional synapses with deep nuclear neurons between postnatal days 2 and 6 (Gardette et al., 1985) and at this time Purkinje cell axons grow many collaterals (Gianola et al., 2003). These recurrent axon collaterals underlie facilitating synapses between cerebellar Purkinje cells (Orduz and Llano, 2007). Interestingly, the Purkinje-Purkinje connection is asymmetric and provides a robust substrate for propagating waves of activity in the developing, but not adult, cerebellum (Watt et al., 2009).

During the first postnatal week, Purkinje cells are contacted by the presynaptic inputs of glutamatergic climbing fibers, the olivocerebellar afferents (Mason et al., 1990; Chedotal and Sotelo, 1992, 1993; Morara et al., 2001). Interestingly during this period, Purkinje cells pass through a phase of climbing fibers multiinnervation (Crepel et al., 1976; Mariani and Changeux, 1981; Kano and Hashimoto, 2009 for review). Some mossy fibers that in adult innervate granule cells can also transiently innervate Purkinje cells (Mason and Gregory, 1984; Takeda and Maekawa, 1989; Kalinovsky et al., 2011). In parallel, some GABAergic axon terminals abut on Purkinje cell somata (Sotelo, 2008; Ichikawa et al., 2011).

At the end of the first postnatal week, the supernumerary climbing fibers begin to be eliminated and the remaining one translocates and synapses onto the proximal dendritic compartment of PCs. The parallel fibers (the axons of granule cells) make synapses at the more distal part of Purkinje cell dendritic tree. In parallel, the different GABAergic interneurons start to innervate specific parts of the Purkinje cell (soma or dendritic tree) (Sotelo, 2008; Ichikawa et al., 2011). Interestingly, during the second postnatal week, considerable fraction of Purkinje somatic spines is succeeded from glutamatergic climbing fibers to GABAergic Basket fibers, in parallel with the switching of postsynaptic receptor phenotypes (Ichikawa et al., 2011).

Thus, at the end of the first postnatal week, the development of Purkinje cells is marked by increase of spinogenesis, synaptogenesis with parallel fibers and GABAergic molecular interneurons (Sotelo and Dusart, 2009; van Welie et al., 2011). In parallel with these events that will continue up to the third postnatal week, there is a transition between depolarizing and hyperpolarizing GABA, and the regression of climbing fiber multi-innervation occurs.

\section{Transition between depolarizing and hyperpolarizing GABA}

Based on two independent sets of experiments (calcium imaging using fura-2 loaded Purkinje cells and perforated-patch recordings) Eilers et al. demonstrated a depolarizing action of GABA on immature Purkinje cells (Eilers et al., 2001). They showed that the transition from depolarization to hyperpolarization occurs around postnatal day 6 (P6) in rats. Interestingly, GABAmediated $\mathrm{Ca}^{2+}$ signaling was never detected in Purkinje cells with more elaborate dendritic trees (aged P8/9). The depolarizing action of GABA has also been observed in Purkinje cells from 3 day-old mice (Rakotomamonjy et al., 2011). Thus Purkinje cells, like some other neuronal populations, exhibit GABA-mediated depolarization during early postnatal stages of life (for review see Ben-Ari et al., 2007). It is thought that GABA depolarizes immature neurons because of a "reversed" chloride gradient in a wide range of neuronal types and animal species (Ben-Ari et al., 2007). The chloride accumulation in immature neurons can be due either to the early expression of transporters such as the Na-K-Cl co-transporter (NKCC) which accumulates chloride within the cell and/or the lack of expression of co-transporters such as $\mathrm{K}-\mathrm{Cl}$ transporter (KCC) that export the chloride out of the cell (Delpire, 2000). For the majority of the neurons, the expression of KCC2 increases indeed at the end of the first postnatal week in rodents (for review see Ben-Ari et al., 2007). Surprisingly, Purkinje cells express KCC2 very early during development (Mikawa et al., 2002; Takayama and Inoue, 2007), but the intracellular chloride concentration can be regulated by other factors, such as the expression of WNK family kinases (Rinehart et al., 2011). How the intracellular chloride concentration is regulated within immature Purkinje cells is still an open question, and it is, therefore, not understood how the transition between GABA depolarization to hyperpolarization would be triggered in this neuron.

\section{Multi-innervation of Purkinje cells by climbing fibers during the first postnatal week}

In the adult, each Purkinje cell receives synapses from only one climbing fiber (mono-innervation). However, just after birth, around $\mathrm{P} 3$ in the rat, several climbing fibers converge and synapse onto the same Purkinje cell body, so that most Purkinje cells are shown to be initially innervated by multiple climbing fibers (Crepel et al., 1976; Mariani and Changeux, 1981). The peak of multi-innervation is around $\mathrm{P} 5$, and the regression of the multi-innervation starts at the end of the first postnatal week. In parallel, there is a translocation of the climbing fibers from the soma to the emergent dendritic tree (Cajal, 1911) although these two events can be dissociated. From this time until the end of the third week, one climbing fiber input is strengthened while supernumerary climbing fibers are weakened and finally eliminated, resulting in mono-innervation of Purkinje cells in the mature system (Hashimoto and Kano, 2003; Hashimoto et al., 2009). As reviewed recently, the phase of synaptic elimination can be divided in two phases: the first is between P7 and P12, and is independent of the parallel fibers; the second phase depends on parallel fibers [for review see (Kano and Hashimoto, 2009)]. Interestingly, it has been shown using co-culture and grafting experiments that climbing fiber synapse elimination occurs 
only during a Purkinje-cell-dependent critical period (Gardette et al., 1990) and triggers indelible processes that prevent synapse competition in the mature system (Letellier et al., 2007, 2009). Whereas numerous actors (such as mGluR1, IGF, BDNF etc.) have been shown to be involved in the second phase of climbing fiber elimination [for review see (Kano and Hashimoto, 2009)], the mechanisms of the first phase at the transition between multi-innervation and regression of this multi-innervation are less understood. The progressive replacement of full-length TrkB by its truncated form on terminal climbing fibers at the end of the first postnatal week is likely to be involved in this process (Sherrard et al., 2009).

\section{DEVELOPMENTAL PURKINJE CELL DEATH ENDS AT THE END OF THE FIRST POSTNATAL WEEK \\ Evidence for developmental Purkinje cell death}

It took a long time for the importance of developmental cell death to be recognized (Ameisen, 2002), and even longer in the case of the Purkinje cell. During the intense phases of cell proliferation, cell death is a counterintuitive notion, and cell death by apoptosis is rapid (about 20-fold faster than proliferation) and difficult to observe directly. Thus, the best way to reveal neuronal cell death during development is to count a population of neurons at different time points. This implies the identification of a neuronal population with specific markers, which were lacking for early Purkinje cells (Madalosso et al., 2005; Dusart et al., 2006). However, numerous early indirect measures suggested that Purkinje cells pass through a phase of programmed cell death during their early development. Some Purkinje cells present pycnotic characteristics in the cerebellar primordium from embryonic day 15-16 (in mouse or chicken; Bertossi et al., 1986). A small number of TUNEL-positive or activated-Caspase3-positive Purkinje cells were observed in the P3-4 mouse cerebellum (Kitao et al., 2004; Marin-Teva et al., 2004). Jankowski et al. (2009) more precisely described the temporal and spatial distribution of pyknotic Purkinje cells during postnatal mouse development, observing dying Purkinje cells during the first postnatal week with a peak at P3, and very few if any pyknotic Purkinje cells after P9.

Furthermore, overexpression of the anti-apoptotic $b c l-2$ gene at various stages of mouse development, and knock-out of the pro-apoptotic bax gene provided indirect indications of the existence and periods of programed developmental Purkinje cell death. Counting numbers of adult Purkinje cells shows a $40 \%$ increase in the transgenic overexpressing bcl-2 either from embryonic day 13 (E13) and a 27\% increase if bcl-2 is overexpressed from $\mathrm{P} 0$, as well as a $30 \%$ increase for the bax deficient mice compared to wild types (Zanjani et al., 1996; Fan et al., 2001). In contrast, the expression of the human $B c l-2$ gene after P7 (using a $\mathrm{L} 7-\mathrm{HuBcl} 2$ transgene, selectively expressed in Purkinje cells) did not change the total number of Purkinje cells, suggesting that the period of Purkinje developmental death ends before P7 (Goswami et al., 2005).

In organotypic culture, good survival is obtained when the cerebellum is explanted between E19 and P0, or after P10. By contrast, the great majority of the Purkinje cells die by apoptosis when the cultures are prepared from cerebellum between P1 and P8, with a maximum of death observed between P3 and P5
(Dusart et al., 1997; Ghoumari et al., 2000, 2002). Thus Purkinje cells are more vulnerable to the culture conditions between P1 and P8. Interestingly during this period, they are also more vulnerable to the noxious effects of alcohol (Pierce et al., 1999). This phase of high vulnerability has been proposed to reflect a period of programmed cell death (Dusart et al., 2005).

All these results suggest the existence of two periods of programmed Purkinje cell death, a first period during the embryonic life between E13-15, and a second period between P3 and P5 (Zanjani et al., 1996). Due to the identification of early Purkinje cell specific markers, it is likely that developmental Purkinje cell death will soon be re-evaluated. It is remarkable that the period of developmental cell death ends for mouse Purkinje cells at the end of the first postnatal week.

\section{Purkinje cell survival factors}

The program of cellular death is generally engaged by default when a mammalian cell is deprived of survival signals released by other cells (Raff et al., 1994). In contrast to other cell types, the vast majority of neurons are not renewed throughout the life of individuals. The neuronal periods of programmed cell death must be, therefore, tightly regulated. During development, neurons depend on trophic factors released by either their targets or their afferents for their survival (Oppenheim, 1991). According to the neurotrophic theory, this dependence allows the adjustment of numbers of neurons with their targets or afferent fibers.

During development, Purkinje cells, like other neurons, are dependent for their survival on signals produced by themselves and by other cellular types. The survival of dissociated and purified Purkinje cells in vitro increases by 14-fold in the presence of astrocytes, and by 32-fold in the presence of granule cells (Baptista et al., 1994). During their maturation, Purkinje cells express the neurotrophin receptors: LNGFR, TrkC, and TrkB (Yan and Johnson, 1988; Cohen-Cory et al., 1989; Lindholm et al., 1993; Minichiello and Klein, 1996; Velier et al., 1997). In parallel, the mRNA encoding neurotrophin-3 (NT-3) is abundant in rat granule cells between P5 and P20 and then replaced by brain-derived neurotrophic factor (BDNF) mRNA (Lindholm et al., 1993; Rocamora et al., 1993; Gao et al., 1995). In addition, Purkinje cells produce both insulin-like growth factor (IGF-1) and its receptor during their postnatal development (Bartlett et al., 1991; Bondy et al., 1992; Garcia-Segura et al., 1997). Interestingly, some of the IGF-1 present in the cerebellar cortex is transported by the climbing fibers from inferior olivary neurons to the Purkinje cells (Nieto-Bona et al., 1995). Furthermore, the deep nuclear neurons, the target of Purkinje cells, also express IGF-1 (Bondy et al., 1992). The mRNA and protein of Glial cell line-derived neurotrophic factor (GDNF) receptor are present in Purkinje cells during development (Burazin and Gundlach, 1999).

After the period of programmed cell death, neurons can survive in the absence of trophic factors or their targets: postnatal sympathetic neurons and septo-hippocampal cholinergic neurons gradually lose their dependency on Nerve Growth Factor or on their targets for survival (Lazarus et al., 1976; Sofroniew et al., 1990, 1993; Svendsen et al., 1994; Orike et al., 2001). Similarly, adult Purkinje cells survive for very long periods in the absence 
of connections with their main target (deep nuclear neurons) and afferents (climbing fibers) (Dusart and Sotelo, 1994; Morel et al., 2002). From the pattern of expression of trophic factors in the developing cerebellum, it is difficult to propose a model to explain why Purkinje cells become independent from the presence of their targets at the end of the first postnatal week. It is likely that this target independence is the consequence of other processes than trophic factor availability.

Organotypic culture has been successfully used to unravel the role of different molecules (Ghoumari et al., 2000, 2002, 2003, 2006; Rakotomamonjy et al., 2011; Repici et al., 2011) and of microglial cells (Marin-Teva et al., 2004) in developmental Purkinje cell death. During the first week of postnatal life, mouse Purkinje cells show high expression of Caspase-3 mRNA (de Bilbao et al., 1999), suggesting that they are competent to die. The role of Lifeguard in Purkinje cell survival has been recently underlined (Hurtado de Mendoza et al., 2011). The mechanisms responsible for closing the period of neuronal target dependence have been studied in depth at the level of the apoptotic pathway (Putcha et al., 2000; Orike et al., 2001; Wright and Deshmukh, 2006; Wright et al., 2007; Vaughn and Deshmukh, 2008; Kole et al., 2011), but it is likely that for the moment, we have only seen the tip of the iceberg.

\section{OTHER PROCESSES WITH A “TRANSITION PHASE" AT THE END OF THE FIRST POSTNATAL WEEK \\ Glial cell differentiation}

The form and cytoskeletal content of Bergmann glia, a cerebellum-specific type of radial glia whose nuclei are in the Purkinje cell layer, change considerably during embryonic and postnatal development. Their content in glial fibrillary acidic protein increases at the end of the first postnatal week (Bovolenta et al., 1984).

Oligodendrocyte precursor cells (OPCs) are already present in the cerebellum at embryonic stages (Levine et al., 1993), but myelination in the mouse cerebellum begins only at the end of the first postnatal week (Foran and Peterson, 1992). Thus, for at least one week, the OPCs are in the presence of Purkinje cell axons but their differentiation is somehow inhibited. The synchronization of cell development is particularly important for cell types that have strong interactions, the case for oligodendrocytes and neurons. OPCs start to differentiate if a mitogenic stimulus is removed or a differentiation stimulus is added, and conversely this cell differentiation is inhibited in the presence of a mitogenic stimulus and the absence of a differentiation stimulus (Durand and Raff, 2000). This delayed differentiation period can be reproduced in vitro using organotypic culture (Bouslama-Oueghlani et al., 2003). However, how OPC and Purkinje cell differentiation are synchronized remains an open question.

\section{Axon regeneration}

Axonal regeneration in the mammalian CNS is a characteristic of immature neurons which is lost during development (Schwab and Bartholdi, 1996; Dusart et al., 2005). Rodent Purkinje cells progressively lose their ability to regenerate their axons during the first postnatal week: axotomy in the early postnatal period is followed by axonal regeneration, but this capacity for regeneration is absent by the second postnatal week (Dusart et al., 1997; Gianola and Rossi, 2001; Ghoumari et al., 2002). Thus, Purkinje cells, like the vast majority of CNS neurons, lose their ability to regenerate their cut axons at the end of the first postnatal week.

\section{A ROLE FOR THYROID HORMONE IN THESE IMPORTANT TRANSITION PROCESSES? EFFECT OF THYROID HORMONE ON PURKINJE CELL DIFFERENTIATION}

Thyroid hormones ( $\mathrm{TH}$, which includes both thyroxine, the inactive precursor and 3,3',5-triiodo-L-thyronine (T3), the active deiodinated derivative) are required for proper neurodevelopment (Oppenheimer and Schwartz, 1997; Koibuchi and Chin, 2000; Bernal, 2007). Whereas the T3 level in serum is remarkably stable in adults, it rapidly increases at birth and peaks during the second week of mouse postnatal development (Hadj-Sahraoui et al., 2000). It should be noted however that the distribution of T3 to neurons is a highly regulated process (Heuer and Visser, 2009), and that the exact T3 concentration sensed by Purkinje cells is unknown (Quignodon et al., 2004). In chicken embryos, it has been proposed that Purkinje cells first gain the ability to convert thyroxine into $\mathrm{T} 3$, increasing local signaling at early stages, and only later express the type 3 deiodinase which catabolizes TH (Verhoelst et al., 2002, 2005). Whether rodent Purkinje cells are also able to metabolize thyroxine and T3 is unknown. In rodents, T3 deficiency results in a number of histological alterations, mainly visible in cerebellum. Purkinje cell alignment is affected, their dendritic arborisations are drastically reduced, and they have fewer synapses. This cellular phenotype can be rescued only if the $\mathrm{TH}$ level is restored at an early stage.

T3 acts directly on gene transcription by binding to nuclear receptors (mainly $\operatorname{TR} \alpha 1$ and $\operatorname{TR} \beta 1$ ), which are both present in Purkinje cells. TR $\alpha 1$ and TR $\beta 1$ not only activate transcription upon T3 binding, but also repress gene expression in the absence of ligand. This explains why knock-out mice usually display a mild phenotype, while major neurological disorders result from point mutations making one isoform dominant negative (Flamant et al., 2002; Morte et al., 2002). The genes activated by ligand-bound TR in Purkinje cells remain completely unknown, but some reports have described changes in Purkinje cell gene expression in hypothyroid animals. For example, Pcp2 (L7) expression is sensitive to TH deficiency, but its down-regulation is only delayed, and reaches normal levels at a later stage, as is the case for several other markers (Strait et al., 1992). This observation is consistent with the possibility that T3 only sets the timing of Purkinje cell differentiation. In line with this theory, the elimination of multiple climbing fiber innervation of Purkinje cells occurs 2-3 days later in hypothyroid animals (Crepel et al., 1981). More recently, T3 treatment in organotypic cultures was found to accelerate the progression of the early steps of Purkinje cell dendritic differentiation (Boukhtouche et al., 2010).

Although this has not been addressed in great detail, it appears that the respective abundance of both T3 receptors changes in Purkinje cells during rodent postnatal development. TR $\alpha 1$ appears to be expressed at birth, and then TR $\beta 1$ expression gradually increases, becoming progressively predominant after 
several weeks (Mellstrom et al., 1991; Bradley et al., 1992; Wallis et al., 2010). Expressing a dominant-negative mutation of either TR $\alpha 1$ (Quignodon et al., 2007; Fauquier et al., 2011) or TR $\beta 1$ (Hashimoto et al., 2001; Portella et al., 2010) is sufficient to affect Purkinje cell differentiation in mice. As the two phenotypes are not identical, a cross-repression between the two receptors appears to be unlikely. The sequential expression of TR $\alpha 1$ and TR $\beta 1$ might be a more plausible explanation: in that case, one should be able to demonstrate that Purkinje cell differentiation is impaired at an earlier stage in TR $\alpha 1$ mutant. Interestingly, primary cultures showed that in vitro morphological changes promoted by $\mathrm{T} 3$ are dependent on $\mathrm{TR} \alpha 1$, not $\mathrm{TR} \beta 1$ (Heuer and Mason, 2003). In humans, many germline mutations have been reported for TR $\beta 1$ which lead to a complex syndrome without obvious cerebellar disorders, known as resistance to thyroid hormone (Weiss and Refetoff, 2000). The first case of a young patient with a TR $\alpha 1$ mutation was recently reported (Bochukova et al., 2012). The child's deficit was consistent with those seen in congenital hypothyroidism.

\section{CELL AUTONOMOUS AND NON-AUTONOMOUS EFFECTS}

T3 also exerts an influence on other cerebellar neuronal and glial cell populations, and can thus influence Purkinje cells indirectly. For example, Bergmann glia promote synapse formation between Purkinje cells and GABAergic interneurons (Ango et al., 2008). As T3 deficiency affects the differentiation of both Bergmann glia (Manzano et al., 2007a) and GABAergic interneurons (Manzano et al., 2007b), it has the potential to explain the observed reduction in synaptogenesis (Nicholson and Altman, 1972; Fauquier et al., 2011). T3 deficiency also impairs the production of neurotrophins by granular neurons, which stimulate Purkinje cell differentiation (Neveu and Arenas, 1996; Koibuchi et al., 2001). As the production of several other neurotrophins and growth factors by Purkinje cells changes as they mature, this creates a situation of interdependence that is very difficult to unravel. Finally, oligodendrocyte precursor differentiation, at least in vitro, is strictly dependent on T3 (Ahlgren et al., 1997; Durand and Raff, 2000). Myelin formation is retarded by T3 deficiency and accelerated by T3 excess (Ibarrola and Rodriguez-Pena, 1997; Marta et al., 1998; Billon et al., 2002). The temporal control exerted by T3 on the differentiation of both Purkinje cells and oligodendrocytes provides a simple hypothetical mechanism to ensure that myelination takes place soon after Purkinje axon outgrowth. Cre/loxP technology was used to address whether T3 activates early oligodendrocytes differentiation and myelin formation in a cell-autonomous manner or not. Whereas expression the dominant negative $\mathrm{TR} \alpha 1$ mutation only in oligodendrocytes precursors had no visible effect on their differentiation, a delay was observed when the mutation was expressed in GABAergic neurons before P8, or when it was expressed in the astrocyte lineage (Picou et al., 2012). The ability of T3 to promote the secretion of several factors at early postnatal stage is thus likely to be determinant in the control exerted on the timing of oligodendrocytes differentiation. In that respect, T3 deficiency could be regarded mainly as a desynchronization of interdependent differentiation processes, whose consequences become rapidly irreversible.

\section{CONCLUSIONS-PERSPECTIVES}

At the end of the first postnatal week, rodent Purkinje cells undergo profound morphological and electrophysiological changes. They also deeply modify their contacts with their other cellular partners. From a cellular point of view, since these transitions occur when TH levels in serum increase (HadjSahraoui et al., 2000), it is tempting to propose that Purkinje cells undergo a metamorphosis: these transitions are reminiscent of amphibian metamorphosis (Tata, 2006) and suggest an interesting analogy (Kress et al., 2009). The recent concern that some chemicals might have neurotoxic effects due to interference with T3 signaling should bring new attention to this process (Ibhazehiebo et al., 2011). Indeed, 1,2,5,6,9,10$\alpha$ Hexabromocyclododecane (HBCD) impairs thyroid hormone induced dendrite arborization of Purkinje cells (Ibhazehiebo et al., 2011).

With our present knowledge, it is very difficult, however, to decipher whether all the processes occurring at this transition period are only concomitant or are truly related. Furthermore, these processes could also be completely independent of TH. It is not known, for example, whether or not axon regeneration or the factors that contribute to chloride concentration within Purkinje cells are driven by TH. During this transition period, it is important to remember that Purkinje cells synthesize other hormones such as progesterone and estradiol (Tsutsui, 2008). Both progesterone and estradiol promote dendritic growth, spinogenesis, and synaptogenesis via their nuclear receptors in developing Purkinje cells (Tsutsui, 2008). Indeed, a large fraction of the 50 members of nuclear receptor family are expressed in Purkinje cells (Qin et al., 2007) suggesting that several of the small ligand molecules that bind these transcription factors are required locally. We have already described the effect of $\operatorname{TR} \alpha, \operatorname{TR} \beta$, and ROR $\alpha$ mutations on Purkinje cells, but rev-erb $\alpha$ and COUP-TFII also affect either the survival or the development of Purkinje cells (Chomez et al., 2000; Kim et al., 2009). Furthermore, T3 action on early Purkinje cell dendritic differentiation requires the presence of functional $\operatorname{ROR} \alpha$ (Boukhtouche et al., 2010). This raises interesting questions concerning interactions between the $\mathrm{TR} \alpha$ and $\operatorname{ROR} \alpha$ signaling pathways (Qiu et al., 2009). Furthermore, the role of $\mathrm{ROR} \alpha$ in later stages of development is unknown.

Finally, the direct target genes of all these nuclear receptors in Purkinje cells, and how these target genes are connected to build or maintain a functioning Purkinje cells, are currently unknown. A major innovation is the systematic development of models with somatic mutations, mainly based on CRE/loxP technology, which allow the analysis of cell autonomous consequences of these mutations (Winter et al., 2009; Fauquier et al., 2011). It will greatly improve our understanding of transcription factors, like $\operatorname{ROR} \alpha$ and $\operatorname{TR} \alpha 1$, which are already well known to be required for Purkinje cell maturation and/or survival but are expressed in many other cell types as well. In such mutant mice, combining Purkinje cell sorting, sequencebased transcriptome analysis and electrophysiology should lead to a better characterization of the Purkinje cell status and pave the way to a deeper understanding of the molecular mechanisms at work. Whether the molecular mechanisms 
governing Purkinje cell differentiation and maturation will be transposable to other cell types is difficult to predict. Whatever the extent of their originality, it is likely that this neuron will continue to occupy the minds of many researchers in the future and bring new important results for developmental neurobiology.

Another open question remains: what could be the role of such a metamorphosis in the rodents? In precocial birds (such as chicken), thyroid function is already well developed during the latter part of incubation and hatchings exhibit relatively mature sensory and locomotor capabilities: these birds are able to walk just after hatching. In contrast in altricial birds (such as dove), thyroid function shows little maturation until after hatch as also is the case for sensory, and motor functions: these birds remains in the nest for a while after hatching (McNabb, 2006). Interestingly, in contrast to rodents, the increase of $\mathrm{TH}$ circulation occurs before birth in sheep, an animal mature enough at birth to walk (Fisher et al., 1994). It remains to demonstrate which components of the metamorphosis of the developing cerebellar microcircuit are indeed triggered by thyroid hormone. However, it is tempting to speculate that in cerebellum as well as in other brain parts the burst availability of high levels of T3 might trigger a general process allowing the animal to switch from a developmental program to a mature one adapted to its final environment.

\section{ACKNOWLEDGMENTS}

The authors thank Ann Lohof for comments on the manuscript. This work has been financially supported by the CNRS, UPMC, ANR-07-NEURO-043-01, and IFP.

\section{REFERENCES}

Ahlgren, S. C., Wallace, H., Bishop, J., Neophytou, C., and Raff, M. C. (1997). Effects of thyroid hormone on embryonic oligodendrocyte precursor cell development in vivo and in vitro. Mol. Cell. Neurosci. 9, 420-432.

Ameisen, J. C. (2002). On the origin, evolution, and nature of programmed cell death: a timeline of four billion years. Cell Death Differ. 9, 367-393.

Ango, F., Wu, C., Van Der Want, J. J., Wu, P., Schachner, M., and Huang, Z. J. (2008). Bergmann glia and the recognition molecule CHL1 organize GABAergic axons and direct innervation of Purkinje cell dendrites. PLoS Biol. 6:e103. doi: 10.1371/journal.pbio.0060103

Armengol, J. A., and Sotelo, C. (1991). Early dendritic development of Purkinje cells in the rat cerebellum. A light and electron microscopic study using axonal tracing in 'in vitro' slices. Brain Res. Dev. Brain Res. 64, 95-114.

Baptista, C. A., Hatten, M. E., Blazeski, R., and Mason, C. A. (1994). Cell-cell interactions influence survival and differentiation of purified Purkinje cells in vitro. Neuron 12, 243-260.

Bartlett, W. P., Li, X. S., Williams, M., and Benkovic, S. (1991). Localization of insulin-like growth factor-1 mRNA in murine central nervous system during postnatal development. Dev. Biol. 147, 239-250.

Ben-Ari, Y., Gaiarsa, J. L., Tyzio, R., and Khazipov, R. (2007). GABA: a pioneer transmitter that excites immature neurons and generates primitive oscillations. Physiol. Rev. 87, 1215-1284.

Bernal, J. (2007). Thyroid hormone receptors in brain development and function. Nat. Clin. Pract. Endocrinol. Metab. 3, 249-259.

Berry, M., and Bradley, P. (1976). The growth of the dendritic trees of Purkinje cells in the cerebellum of the rat. Brain Res. 112, 1-35.

Bertossi, M., Roncali, L., Mancini, L., Ribatti, D., and Nico, B. (1986). Process of differentiation of cerebellar Purkinje neurons in the chick embryo. Anat. Embryol. (Berl.) 175, 25-34.

Billon, N., Jolicoeur, C., Tokumoto, Y., Vennstrom, B., and Raff, M. (2002). Normal timing of oligodendrocyte development depends on thyroid hormone receptor alpha 1 (TRalpha1). EMBO J. 21, 6452-6460.

Bochukova, E., Schoenmakers, N., Agostini, M., Schoenmakers, E., Rajanayagam, O., Keogh, J. M., Henning, E., Reinemund, J., Gevers, E., Sarri, M., Downes, K., Offiah, A., Albanese, A., Halsall, D., Schwabe, J. W., Bain, M., Lindley, K., Muntoni, F., Khadem, F. V., Dattani, M., Farooqi, I. S., Gurnell, M., and Chatterjee, K. (2012). A mutation in the thyroid hormone receptor alpha gene. N. Engl. J. Med. 366, 243-249.

Bondy, C., Werner, H., Roberts, C. T., and Leroith, D. (1992). Cellular pattern of type-I insulin-like growth factor receptor gene expression during maturation of the rat brain: comparison with insulin-like growth factors I and II. Neuroscience 46, 909-923.

Boukhtouche, F., Brugg, B., Wehrle, R., Bois-Joyeux, B., Danan, J. L., Dusart, I., and Mariani, J. (2010). Induction of early Purkinje cell dendritic differentiation by thyroid hormone requires RORalpha. Neural Dev. 5, 18 .

Boukhtouche, F., Doulazmi, M. Frederic, F., Dusart, I., Brugg, B., and Mariani, J. (2006a). RORalpha, a pivotal nuclear receptor for Purkinje neuron survival and differentiation: from development to ageing. Cerebellum 5, 97-104.

Boukhtouche, F., Janmaat, S., Vodjdani, G., Gautheron, V., Mallet, J., Dusart, I., and Mariani, J. (2006b) Retinoid-related orphan receptor alpha controls the early steps of Purkinje cell dendritic differentiation. J. Neurosci. 26 , 1531-1538.

Bouslama-Oueghlani, L., Wehrle, R., Sotelo, C., and Dusart, I. (2003). The developmental loss of the ability of Purkinje cells to regenerate their axons occurs in the absence of myelin: an in vitro model to prevent myelination. J. Neurosci. 23 8318-8329.

Bovolenta, P., Liem, R. K., and Mason, C. A. (1984). Development of cerebellar astroglia: transitions in form and cytoskeletal content. Dev. Biol. 102, 248-259.

Bradley, D. J., Towle, H. C., and Young, W. S. 3rd. (1992). Spatial and temporal expression of alpha- and betathyroid hormone receptor mRNAs, including the beta 2-subtype, in the developing mammalian nervous system. J. Neurosci. 12, 2288-2302.

Bradley, P., and Berry, M. (1976). The effects of reduced climbing and parallel fibre input on Purkinje cell dendritic growth. Brain Res. 109, 133-151.

Burazin, T. C., and Gundlach, A. L. (1999). Localization of GDNF/neurturin receptor (c-ret, GFRalpha-1 and alpha-2) mRNAs in postnatal rat brain: differential regional and temporal expression in hippocampus, cortex and cerebellum. Brain Res. Mol. Brain Res. 73, 151-171.

Cajal, R. (1911). Histologie du Système Nerveux de l'homme et des Vertébrés. Paris: Maloine.
Cajal, R. (1926). Sur les fibres moussues et quelques points douteux de la texture de l'écorce cérébelleuse. Trab. Lab. Invest. Biol. Univ. Madrid 24, 215-251.

Carletti, B., and Rossi, F. (2008) Neurogenesis in the cerebellum. Neuroscientist 14, 91-100.

Chedotal, A., and Sotelo, C. (1992). Early development of olivocerebellar projections in the fetal rat using CGRP immunocytochemistry. Eur. J. Neurosci. 4, 1159-1179.

Chedotal, A., and Sotelo, C. (1993). The 'creeper stage' in cerebellar climbing fiber synaptogenesis precedes the 'pericellular nest'ultrastructural evidence with parvalbumin immunocytochemistry. Brain Res. Dev. Brain Res. 76, 207-220.

Chomez, P., Neveu, I., Mansen, A., Kiesler, E., Larsson, L., Vennstrom, B., and Arenas, E. (2000). Increased cell death and delayed development in the cerebellum of mice lacking the rev-erbA(alpha) orphan receptor. Development 127 . 1489-1498.

Cohen-Cory, S., Dreyfus, C. F., and Black, I. B. (1989). Expression of high- and low-affinity nerve growth factor receptors by Purkinje cells in the developing rat cerebellum. Exp. Neurol. 105, 104-109.

Crepel, F., Delhaye-Bouchaud, N., and Dupont, J. L. (1981). Fate of the multiple innervation of cerebellar Purkinje cells by climbing fibers in immature control, $x$-irradiated and hypothyroid rats. Brain Res. 227, 59-71.

Crepel, F., Mariani, J., and DelhayeBouchaud, N. (1976). Evidence for a multiple innervation of Purkinje cells by climbing fibers in the immature rat cerebellum. J. Neurobiol. 7, 567-578. 
de Bilbao, F., Guarin, E., Nef, P., Vallet, P., Giannakopoulos, P., and DuboisDauphin, M. (1999). Postnatal distribution of cpp32/caspase 3 mRNA in the mouse central nervous system: an in situ hybridization study. J. Comp. Neurol. 409, 339-357.

Delpire, E. (2000). Cation-chloride cotransporters in neuronal communication. News Physiol. Sci. 15, 309-312.

Durand, B., and Raff, M. (2000). A cellintrinsic timer that operates during oligodendrocyte development. Bioessays 22, 64-71.

Dusart, I., Airaksinen, M. S., and Sotelo, C. (1997). Purkinje cell survival and axonal regeneration are age dependent: an in vitro study. J. Neurosci. 17, 3710-3726.

Dusart, I., Ghoumari, A., Wehrle, R., Morel, M. P., Bouslama-Oueghlani, L., Camand, E., and Sotelo, C. (2005). Cell death and axon regeneration of Purkinje cells after axotomy: challenges of classical hypotheses of axon regeneration. Brain Res. Brain Res. Rev. 49, 300-316.

Dusart, I., Guenet, J. L., and Sotelo, C. (2006). Purkinje cell death: differences between developmental cell death and neurodegenerative death in mutant mice. Cerebellum 5, 163-173.

Dusart, I., and Sotelo, C. (1994). Lack of Purkinje cell loss in adult rat cerebellum following protracted axotomy: degenerative changes and regenerative attempts of the severed axons. J. Comp. Neurol. 347, 211-232.

Eilers, J., Plant, T. D., Marandi, N., and Konnerth, A. (2001). GABAmediated $\mathrm{Ca}^{2+}$ signalling in developing rat cerebellar Purkinje neurones. J. Physiol. 536, 429-437.

Eisenman, L. M., Schalekamp, M. P., and Voogd, J. (1991). Development of the cerebellar cortical efferent projection: an in-vitro anterograde tracing study in rat brain slices. Brain Res. Dev. Brain Res. 60, 261-266.

Fan, H., Favero, M., and Vogel, M. W. (2001). Elimination of Bax expression in mice increases cerebellar Purkinje cell numbers but not the number of granule cells. J. Comp. Neurol. 436, 82-91.

Fauquier, T., Romero, E., Picou, F., Chatonnet, F., Nguyen, X. N., Quignodon, L., and Flamant, F, (2011). Severe impairment of cerebellum development in mice expressing a dominant-negative mutation inactivating thyroid hormone receptor alphal isoform. Dev. Biol. 356, 350-358.
Fisher, D. A., Polk, D. H., and Wu, S. Y. (1994). Fetal thyroid metabolism: a pluralistic system. Thyroid 4, 367-371.

Flamant, F., Poguet, A. L., Plateroti, M., Chassande, O., Gauthier, K., Streichenberger, N., Mansouri, A., and Samarut, J. (2002). Congenital hypothyroid Pax8(-/-) mutant mice can be rescued by inactivating the TRalpha gene. Mol. Endocrinol. 16, 24-32.

Foran, D. R., and Peterson, A. C. (1992). Myelin acquisition in the central nervous system of the mouse revealed by an MBPLac Z transgene. J. Neurosci. 12, 4890-4897.

Gao, W. Q., Zheng, J. L., and Karihaloo, M. (1995). Neurotrophin-4/5 (NT-4/5) and brain-derived neurotrophic factor (BDNF) act at later stages of cerebellar granule cell differentiation. J. Neurosci. 15, 2656-2667.

Garcia-Segura, L. M., Rodriguez, J. R., and Torres-Aleman, I. (1997). Localization of the insulin-like growth factor I receptor in the cerebellum and hypothalamus of adult rats: an electron microscopic study. J. Neurocytol. 26, 479-490.

Gardette, R., Crepel, F., AlvaradoMallart, R. M., and Sotelo, C. (1990). Fate of grafted embryonic Purkinje cells in the cerebellum of the adult "Purkinje cell degeneration" mutant mouse. II. Development of synaptic responses: an in vitro study. J. Comp. Neurol. 295, 188-196.

Gardette, R., Debono, M., Dupont, J. L., and Crepel, F. (1985). Electrophysiological studies on the postnatal development of intracerebellar nuclei neurons in rat cerebellar slices maintained in vitro. I. Postsynaptic potentials. Brain Res. $351,47-55$.

Ghoumari, A. M., Dusart, I., ElEtr, M., Tronche, F., Sotelo, C., Schumacher, M., and Baulieu, E. E. (2003). Mifepristone (RU486) protects Purkinje cells from cell death in organotypic slice cultures of postnatal rat and mouse cerebellum. Proc. Natl. Acad. Sci. U.S.A. 100, 7953-7958.

Ghoumari, A. M., Piochon, C., Tomkiewicz, C., Eychenne, B., Levenes, C., Dusart, I., Schumacher, M., and Baulieu, E. E. (2006). Neuroprotective effect of mifepristone involves neuron depolarization. FASEB J. 20, 1377-1386.

Ghoumari, A. M., Wehrle, R., Bernard, O., Sotelo, C., and Dusart, I. (2000).
Implication of Bcl-2 and Caspase-3 in age-related Purkinje cell death in murine organotypic culture: an in vitro model to study apoptosis. Eur. J. Neurosci. 12, 2935-2949.

Ghoumari, A. M., Wehrle, R., De Zeeuw, C. I., Sotelo, C., and Dusart, I. (2002). Inhibition of protein kinase C prevents Purkinje cell death but does not affect axonal regeneration. J. Neurosci. 22, 3531-3542.

Gianola, S., and Rossi, F. (2001) Evolution of the Purkinje cell response to injury and regenerative potential during postnatal development of the rat cerebellum. J. Comp. Neurol. 430, 101-117.

Gianola, S., Savio, T., Schwab, M. E., and Rossi, F. (2003). Cellautonomous mechanisms and myelin-associated factors contribute to the development of Purkinje axon intracortical plexus in the rat cerebellum. J. Neurosci. 23, 4613-4624.

Gold, D. A., Gent, P. M., and Hamilton, B. A. (2007). ROR alpha in genetic control of cerebellum development: 50 staggering years. Brain Res. 1140 19-25.

Goswami, J., Martin, L. A., Goldowitz, D., Beitz, A. J., and Feddersen, R. M (2005). Enhanced Purkinje cell survival but compromised cerebellar function in targeted anti-apoptotic protein transgenic mice. Mol. Cell. Neurosci. 29, 202-221.

Hadj-Sahraoui, N., Seugnet, I., Ghorbel, M. T., and Demeneix, B. (2000). Hypothyroidism prolongs mitotic activity in the post-natal mouse brain. Neurosci. Lett. 280 79-82.

Hamilton, B. A., Frankel, W. N., Kerrebrock, A. W., Hawkins, T. L., Fitzhugh, W., Kusumi, K., Russell, L. B., Mueller, K. L., Van Berkel, V., Birren, B. W., Kruglyak, L., and Lander, E. S. (1996). Disruption of the nuclear hormone receptor RORalpha in staggerer mice. Nature 379, 736-739.

Hashimoto, K., Curty, F. H., Borges, P. P., Lee, C. E., Abel, E. D., Elmquist, J. K., Cohen, R. N., and Wondisford, F. E. (2001). An unliganded thyroid hormone receptor causes severe neurological dysfunction. Proc. Natl. Acad. Sci. U.S.A. 98 3998-4003.

Hashimoto, K., Ichikawa, R., Kitamura, K., Watanabe, M., and Kano, M (2009). Translocation of a "winner" climbing fiber to the Purkinje cell dendrite and subsequent elimination of "losers" from the soma in developing cerebellum. Neuron 63, 106-118.
Hashimoto, K., and Kano, M. (2003). Functional differentiation of multiple climbing fiber inputs during synapse elimination in the developing cerebellum. Neuron 38, 785-796.

Heuer, H., and Mason, C. A. (2003). Thyroid hormone induces cerebellar Purkinje cell dendritic development via the thyroid hormone receptor alpha1. J. Neurosci. 23, 10604-10612.

Heuer, H., and Visser, T. J. (2009). Minireview: pathophysiological importance of thyroid hormone transporters. Endocrinology 150, 1078-1083.

Hurtado de Mendoza, T., Perez-Garcia, C. G., Kroll, T. T., Hoong, N. H., O'Leary, D. D., and Verma, I. M. (2011). Antiapoptotic protein Lifeguard is required for survival and maintenance of Purkinje and granular cells. Proc. Natl. Acad. Sci. U.S.A. 108, 17189-17194.

Ibarrola, N., and Rodriguez-Pena, A. (1997). Hypothyroidism coordinately and transiently affects myelin protein gene expression in most rat brain regions during postnatal development. Brain Res. 752, 285-293.

Ibhazehiebo, K., Iwasaki, T., Shimokawa, N., and Koibuchi, N. (2011). 1,2,5,6,9,10-alphaHexabromocyclododecane (HBCD) impairs thyroid hormone-induced dendrite arborization of Purkinje cells and suppresses thyroid hormone receptor-mediated transcription. Cerebellum 10, 22-31.

Ichikawa, R., Yamasaki, M., Miyazaki, T., Konno, K., Hashimoto, K. Tatsumi, H., Inoue, Y., Kano, M., and Watanabe, M. (2011). Developmental switching of perisomatic innervation from climbing fibers to basket cell fibers in cerebellar Purkinje cells. J. Neurosci. 31, 16916-16927.

Jankowski, J., Miething, A., Schilling, K., and Baader, S. L. (2009). Physiological Purkinje cell death is spatiotemporally organized in the developing mouse cerebellum. Cerebellum 8, 277-290.

Kalinovsky, A., Boukhtouche, F., Blazeski, R., Bornmann, C., Suzuki, N., Mason, C. A., and Scheiffele, P. (2011). Development of axon-target specificity of ponto-cerebellar afferents. PLoS Biol. 9:e1001013. doi 10.1371/journal.pbio.1001013

Kaneko, M., Yamaguchi, K., Eiraku, M., Sato, M., Takata, N., Kiyohara, Y., Mishina, M., Hirase, H., Hashikawa, T., and Kengaku, M. (2011). Remodeling of monoplanar Purkinje cell dendrites 
during cerebellar circuit formation. PLoS One 6:e20108. doi: 10.1371/journal.pone.0020108

Kano, M., and Hashimoto, K. (2009). Synapse elimination in the central nervous system. Curr. Opin. Neurobiol. 19, 154-161.

Kim, B. J., Takamoto, N., Yan, J., Tsai, S. Y., and Tsai, M. J. (2009). Chicken Ovalbumin Upstream Promoter-Transcription Factor II (COUP-TFII) regulates growth and patterning of the postnatal mouse cerebellum. Dev. Biol. 326, 378-391.

Kitao, Y., Hashimoto, K., Matsuyama, T., Iso, H., Tamatani, T., Hori, O., Stern, D. M., Kano, M., Ozawa, K., and Ogawa, S. (2004). ORP150/HSP12A regulates Purkinje cell survival: a role for endoplasmic reticulum stress in cerebellar development. J. Neurosci. 24, 1486-1496.

Koibuchi, N., and Chin, W. W. (2000). Thyroid hormone action and brain development. Trends Endocrinol. Metab. 11, 123-128.

Koibuchi, N., Yamaoka, S., and Chin, W. W. (2001). Effect of altered thyroid status on neurotrophin gene expression during postnatal development of the mouse cerebellum. Thyroid 11, 205-210.

Kole, A. J., Swahari, V., Hammond, S. M., and Deshmukh, M. (2011). miR-29b is activated during neuronal maturation and targets $\mathrm{BH} 3$ only genes to restrict apoptosis. Genes Dev. 25, 125-130.

Kress, E., Samarut, J., and Plateroti, M. (2009). Thyroid hormones and the control of cell proliferation or cell differentiation: paradox or duality? Mol. Cell. Endocrinol. 313, 36-49.

Kriaucionis, S., and Heintz, N. (2009). The nuclear DNA base 5-hydroxymethylcytosine is present in Purkinje neurons and the brain. Science 324, 929-930.

Larramendi, L. M. (1969). "Analysis of synaptogenesis in the cerebellum of the mouse," in Neurobiology of Cerebellar Evolution and Development, ed R. Llinas (Chicago: American Medical Association), 803-843.

Lazarus, K. J., Bradshaw, R. A., West, N. R., and Bunge, P. (1976). Adaptive survival or rat sympathetic neurons cultured without supporting cells or exogenous nerve growth factor. Brain Res. 113, 159-164.

Letellier, M., Bailly, Y., Demais, V., Sherrard, R. M., Mariani, J., and Lohof, A. M. (2007). Reinnervation of late postnatal Purkinje cells by climbing fibers: neosynaptogenesis without transient multi-innervation. J. Neurosci. 27, 5373-5383.

Letellier, M., Wehrle, R., Mariani, J., and Lohof, A. M. (2009). Synapse elimination in olivo-cerebellar explants occurs during a critical period and leaves an indelible trace in Purkinje cells. Proc. Natl. Acad. Sci. U.S.A. 106, 14102-14107.

Levine, J. M., Stincone, F., and Lee, Y. S. (1993). Development and differentiation of glial precursor cells in the rat cerebellum. Glia 7, 307-321.

Lindholm, D., Castren, E., Tsoulfas, P., Kolbeck, R., Berzaghi Mda, P., Leingartner, A., Heisenberg, C. P., Tessarollo, L., Parada, L. F., and Thoenen, H. (1993). Neurotrophin3 induced by tri-iodothyronine in cerebellar granule cells promotes Purkinje cell differentiation. J. Cell Biol. 122, 443-450.

Madalosso, S. H., Perez-Villegas, E. M., and Armengol, J. A. (2005). Naturally occurring neuronal death during the postnatal development of Purkinje cells and their precerebellar afferent projections. Brain Res. Brain Res. Rev. 49, 267-279.

Manzano, J., Bernal, J., and Morte, B. (2007a). Influence of thyroid hormones on maturation of rat cerebellar astrocytes. Int. J. Dev. Neurosci. $25,171-179$.

Manzano, J., Cuadrado, M., Morte, B., and Bernal, J. (2007b). Influence of thyroid hormone and thyroid hormone receptors in the generation of cerebellar gamma-aminobutyric acid-ergic interneurons from precursor cells. Endocrinology 148, 5746-5751.

Mariani, J., and Changeux, J. P. (1981). Ontogenesis of olivocerebellar relationships. I. Studies by intracellular recordings of the multiple innervation of Purkinje cells by climbing fibers in the developing rat cerebellum. J. Neurosci. 1, 696-702.

Marin-Teva, J. L., Dusart, I., Colin, C., Gervais, A., Van Rooijen, N., and Mallat, M. (2004). Microglia promote the death of developing Purkinje cells. Neuron 41, 535-547.

Marta, C. B., Adamo, A. M., Soto, E. F., and Pasquini, J. M. (1998). Sustained neonatal hyperthyroidism in the rat affects myelination in the central nervous system. J. Neurosci. Res. 53, 251-259.

Mason, C. A., Christakos, S., and Catalano, S. M. (1990). Early climbing fiber interactions with Purkinje cells in the postnatal mouse cerebellum. J. Comp. Neurol. 297, 77-90.

Mason, C. A., and Gregory, E. (1984). Postnatal maturation of cerebellar mossy and climbing fibers: transient expression of dual features on single axons. J. Neurosci. 4 1715-1735.

McNabb, F. M. (2006). Avian thyroid development and adaptive plasticity. Gen. Comp. Endocrinol. 147, 93-101.

Mellstrom, B., Naranjo, J. R., Santos, A., Gonzalez, A. M., and Bernal, J. (1991). Independent expression of the alpha and beta c-erbA genes in developing rat brain. Mol. Endocrinol. 5, 1339-1350.

Miale, I. L., and Sidman, R. L. (1961) An autoradiographic analysis of histogenesis in the mouse cerebellum. Exp. Neurol. 4, 277-296.

Mikawa, S., Wang, C., Shu, F., Wang, T., Fukuda, A., and Sato, K. (2002) Developmental changes in $\mathrm{KCC} 1$, KCC2 and NKCC1 mRNAs in the rat cerebellum. Brain Res. Dev. Brain Res. 136, 93-100.

Minichiello, L., and Klein, R. (1996). TrkB and TrkC neurotrophin receptors cooperate in promoting survival of hippocampal and cerebellar granule neurons. Genes Dev. 10, 2849-2858.

Morara, S., Van Der Want, J. J., De Weerd, H., Provini, L., and Rosina, A. (2001). Ultrastructural analysis of climbing fiber-Purkinje cell synaptogenesis in the rat cerebellum. Neuroscience 108, 655-671.

Morel, M. P., Dusart, I., and Sotelo, C. (2002). Sprouting of adult Purkinje cell axons in lesioned mouse cerebellum: "non-permissive" versus "permissive" environment. J. Neurocytol. 31, 633-647.

Morte, B., Manzano, J., Scanlan, T., Vennstrom, B., and Bernal, J. (2002). Deletion of the thyroid hormone receptor alpha 1 prevents the structural alterations of the cerebellum induced by hypothyroidism. Proc. Natl. Acad. Sci. U.S.A. 99, 3985-3989.

Neveu, I., and Arenas, E. (1996) Neurotrophins promote the survival and development of neurons in the cerebellum of hypothyroid rats in vivo. J. Cell Biol. 133, 631-646.

Nicholson, J. L., and Altman, J. (1972). Synaptogenesis in the rat cerebellum: effects of early hypo- and hyperthyroidism. Science 176, 530-532.

Nieto-Bona, M. P., Busiguina, S., and Torres-Aleman, I. (1995). Insulinlike growth factor $\mathrm{I}$ is an afferent trophic signal that modulates calbindin-28kD in adult Purkinje cells. J. Neurosci. Res. 42, 371-376.

Oppenheim, R. W. (1991). Cell death during development of the nervous system. Annu. Rev. Neurosci. 14, 453-501.

Oppenheimer, J. H., and Schwartz, H. L. (1997). Molecular basis of thyroid hormone-dependent brain development. Endocr. Rev. 18, 462-475.

Orduz, D., and Llano, I. (2007). Recurrent axon collaterals underlie facilitating synapses between cerebellar Purkinje cells. Proc. Natl. Acad. Sci. U.S.A. 104, 17831-17836.

Orike, N., Middleton, G., Borthwick, E., Buchman, V., Cowen, T., and Davies, A. M. (2001). Role of PI 3-kinase, Akt and Bcl-2-related proteins in sustaining the survival of neurotrophic factor-independent adult sympathetic neurons. J. Cell Biol. 154, 995-1005.

Picou, T., Fauquier, F., Chatonnet, F., and Flamant, F. (2012). A bimodal influence of thyroid hormone on cerebellum oligodendrocyte differentiation. Mol. Endocrinol. 26, 608-618.

Pierce, D. R., Williams, D. K., and Light, K. E. (1999). Purkinje cell vulnerability to developmental ethanol exposure in the rat cerebellum. Alcohol. Clin. Exp. Res. 23, 1650-1659.

Portella, A. C., Carvalho, F., Faustino, L., Wondisford, F. E., OrtigaCarvalho, T. M., and Gomes, F. C. (2010). Thyroid hormone receptor beta mutation causes severe impairment of cerebellar development. Mol. Cell. Neurosci. 44, 68-77.

Poulain, F. E., Chauvin, S., Wehrle, R., Desclaux, M., Mallet, J., Vodjdani, G., Dusart, I., and Sobel, A. (2008). SCLIP is crucial for the formation and development of the Purkinje cell dendritic arbor. J. Neurosci. 28, 7387-7398.

Putcha, G. V., Deshmukh, M., and Johnson, E. M. Jr. (2000). Inhibition of apoptotic signaling cascades causes loss of trophic factor dependence during neuronal maturation. J. Cell Biol. 149, 1011-1018.

Qin, J., Suh, J. M., Kim, B. J., Yu, C. T., Tanaka, T., Kodama, T., Tsai, M. J., and Tsai, S. Y. (2007). The expression pattern of nuclear receptors during cerebellar development. Dev. Dyn. 236, 810-820.

Qiu, C. H., Miyazaki, W., Iwasaki, T., Londono, M., Ibhazehiebo, K., Shimokawa, N., and Koibuchi, N. (2009). Retinoic Acid receptor-related orphan receptor alpha-enhanced thyroid hormone receptor-mediated transcription requires its ligand binding domain which is not, by itself, sufficient: possible direct interaction of two receptors. Thyroid 19, 893-898. 
Quignodon, L., Legrand, C., Allioli, N., Guadano-Ferraz, A., Bernal, J., Samarut, J., and Flamant, F. (2004). Thyroid hormone signaling is highly heterogeneous during preand postnatal brain development. J. Mol. Endocrinol. 33, 467-476.

Quignodon, L., Vincent, S., Winter, H., Samarut, J., and Flamant, F. (2007). A point mutation in the activation function 2 domain of thyroid hormone receptor alphal expressed after CRE-mediated recombination partially recapitulates hypothyroidism. Mol. Endocrinol. 21, 2350-2360.

Raff, M. C., Barres, B. A., Burne, J. F., Coles, H. S., Ishizaki, Y., and Jacobson, M. D. (1994). Programmed cell death and the control of cell survival. Philos. Trans. R. Soc. Lond. B Biol. Sci. 345, 265-268.

Rakotomamonjy, J., Levenes, C., Baulieu, E. E., Schumacher, M., and Ghoumari, A. M. (2011). Novel protective effect of mifepristone on detrimental GABAA receptor activity to immature Purkinje neurons. FASEB J. 25, 3999-4010.

Repici, M., Wehrle, R., Antoniou, X., Borsello, T., and Dusart, I. (2011). c-Jun N-terminal kinase (JNK) and p38 play different roles in age-related Purkinje cell death in murine organotypic culture. Cerebellum 10, 281-290.

Rinehart, J., Vazquez, N., Kahle, K. T., Hodson, C. A., Ring, A. M., Gulcicek, E. E., Louvi, A., Bobadilla, N. A., Gamba, G., and Lifton, R. P. (2011). WNK2 kinase is a novel regulator of essential neuronal cation-chloride cotransporters. J. Biol. Chem. 286, 30171-30180.

Rocamora, N., Garcia-Ladona, F. J., Palacios, J. M., and Mengod, G. (1993). Differential expression of brain-derived neurotrophic factor, neurotrophin-3, and low-affinity nerve growth factor receptor during the postnatal development of the rat cerebellar system. Brain Res. Mol. Brain Res. 17, 1-8.

Sajan, S. A., Waimey, K. E., and Millen, K. J. (2010). Novel approaches to studying the genetic basis of cerebellar development. Cerebellum 9, 272-283.

Schwab, M. E., and Bartholdi, D. (1996). Degeneration and regeneration of axons in the lesioned spinal cord. Physiol. Rev. 76, 319-370.
Sherrard, R. M., Dixon, K. J., Bakouche, J., Rodger, J., Lemaigre-Dubreuil, Y., and Mariani, J. (2009). Differential expression of TrkB isoforms switches climbing fiber-Purkinje cell synaptogenesis to selective synapse elimination. Dev. Neurobiol. 69, 647-662.

Sidman, R. L., Lane, P. W., and Dickie, M. M. (1962). Staggerer, a new mutation in the mouse affecting the cerebellum. Science 137, 610-612.

Sofroniew, M. V., Cooper, J. D., Svendsen, C. N., Crossman, P., Lindsay, R. M., Zafra, F., and Lindholm, D. (1993). Atrophy but not death of adult septal cholinergic neurons after ablation of target capacity to produce mRNAs for NGF, BDNF, and NT3. J. Neurosci. 13, 5263-5276.

Sofroniew, M. V., Galletly, N. P., Isacson, O., and Svendsen, C. N. (1990). Survival of adult basal forebrain cholinergic neurons after loss of target neurons. Science 247, 338-342.

Sotelo, C. (2004). Cellular and genetic regulation of the development of the cerebellar system. Prog. Neurobiol. $72,295-339$.

Sotelo, C. (2008). Development of "Pinceaux" formations and dendritic translocation of climbing fibers during the acquisition of the balance between glutamatergic and gamma-aminobutyric acidergic inputs in developing Purkinje cells. J. Comp. Neurol. 506, 240-262.

Sotelo, C., and Dusart, I. (2009). Intrinsic versus extrinsic determinants during the development of Purkinje cell dendrites. Neuroscience 162, 589-600.

Strait, K. A., Zou, L., and Oppenheimer, J. H. (1992). Beta 1 isoform-specific regulation of a triiodothyronineinduced gene during cerebellar development. Mol. Endocrinol. 6, 1874-1880.

Svendsen, C. N., Kew, J. N., Staley, K., and Sofroniew, M. V. (1994). Death of developing septal cholinergic neurons following NGF withdrawal in vitro: protection by protein synthesis inhibition. J. Neurosci. $14,75-87$.

Takayama, C., and Inoue, Y. (2007). Developmental localization of potassium chloride co-transporter 2 (KCC2) in the Purkinje cells of embryonic mouse cerebellum. Neurosci. Res. 57, 322-325.

Takeda, T., and Maekawa, K. (1989). Transient direct connection of vestibular mossy fibers to the vestibulocerebellar Purkinje cells in early postnatal development of kittens. Neuroscience 32, 99-111.

Tata, J. R. (2006). Amphibian metamorphosis as a model for the developmental actions of thyroid hormone. Mol. Cell. Endocrinol. 246, 10-20.

Tsutsui, K. (2008). Neurosteroids in the Purkinje cell: biosynthesis, mode of action and functional significance. Mol. Neurobiol. 37, 116-125.

van Welie, I., Smith, I. T., and Watt, A. J. (2011). The metamorphosis of the developing cerebellar microcircuit. Curr. Opin. Neurobiol. 21, 245-253.

Vaughn, A. E., and Deshmukh, M. (2008). Glucose metabolism inhibits apoptosis in neurons and cancer cells by redox inactivation of cytochrome c. Nat. Cell Biol. 10, 1477-1483.

Velier, J. J., Ellison, J. A., Fisher, R. S., and Vinters, H. V. (1997). The trkC receptor is transiently localized to Purkinje cell dendrites during outgrowth and maturation in the rat. J. Neurosci. Res. 50, 649-656.

Verhoelst, C. H., Roelens, S. A., and Darras, V. M. (2005). Role of spatiotemporal expression of iodothyronine deiodinase proteins in cerebellar cell organization. Brain Res. Bull. 67, 196-202.

Verhoelst, C. H., Vandenborne, K. Severi, T., Bakker, O., Zandieh Doulabi, B., Leonard, J. L., Kuhn, E. R., Van Der Geyten, S., and Darras, V. M. (2002). Specific detection of type III iodothyronine deiodinase protein in chicken cerebellar purkinje cells. Endocrinology 143, 2700-2707.

Wallis, K., Dudazy, S., Van Hogerlinden, M., Nordstrom, K., Mittag, J., and Vennstrom, B. (2010). The Thyroid hormone receptor $\{$ alpha\} 1 protein is expressed in embryonic postmitotic neurons and persists in most adult neurons. Mol. Endocrinol. 24, 1904-1916.

Watt, A. J., Cuntz, H., Mori, M., Nusser, Z., Sjostrom, P. J., and Hausser, M. (2009). Traveling waves in developing cerebellar cortex mediated by asymmetrical Purkinje cell connectivity. Nat. Neurosci. 12, 463-473.
Weiss, R. E., and Refetoff, S. (2000). Resistance to thyroid hormone. Rev. Endocr. Metab. Disord. 1, 97-108.

Winter, H., Ruttiger, L., Muller, M., Kuhn, S., Brandt, N., Zimmermann, U., Hirt, B., Bress, A., Sausbier, M., Conscience, A., Flamant, F., Tian, Y., Zuo, J., Pfister, M., Ruth, P., Lowenheim, H., Samarut, J., Engel, J., and Knipper, M. (2009). Deafness in TRbeta mutants is caused by malformation of the tectorial membrane. J. Neurosci. 29, 2581-2587.

Wright, K. M., and Deshmukh, M. (2006). Restricting apoptosis for postmitotic cell survival and its relevance to cancer. Cell Cycle 5, 1616-1620.

Wright, K. M., Smith, M. I., Farrag L., and Deshmukh, M. (2007). Chromatin modification of Apaf-1 restricts the apoptotic pathway in mature neurons. J. Cell Biol. 179, 825-832.

Yan, Q., and Johnson, E. M. Jr. (1988). An immunohistochemical study of the nerve growth factor receptor in developing rats. J. Neurosci. 8, 3481-3498.

Zanjani, H. S., Vogel, M. W., DelhayeBouchaud, N., Martinou, J. C., and Mariani, J. (1996). Increased cerebellar Purkinje cell numbers in mice overexpressing a human bcl-2 transgene. J. Comp. Neurol. 374, 332-341.

Conflict of Interest Statement: The authors declare that the research was conducted in the absence of any commercial or financial relationships that could be construed as a potential conflict of interest.

Received: 02 December 2011; accepted: 23 March 2012; published online: 11 April 2012.

Citation: Dusart I and Flamant F (2012) Profound morphological and functional changes of rodent Purkinje cells between the first and the second postnatal weeks: a metamorphosis?. Front. Neuroanat. 6:11. doi: 10.3389/fnana.2012.00011

Copyright (๑) 2012 Dusart and Flamant. This is an open-access article distributed under the terms of the Creative Commons Attribution Non Commercial License, which permits non-commercial use, distribution, and reproduction in other forums, provided the original authors and source are credited. 